\title{
Inquiry Based Teaching Material Development Guided in Calor and Materials the Transfer of Class V Primary State 2 Alue Teh
}

\author{
Santi Dewi ${ }^{1}$, Fauziah Harahap ${ }^{2}$, Adi Sutopo ${ }^{3}$ \\ ${ }^{1}$ Postgraduate Program in Universitas Negeri Medan, Indonesia \\ ${ }^{2,3}$ Universitas Negeri Medan, Indonesia
}

\section{Abstract}

Development of Inquiry-Based Teaching Materials Guided by the Material of Heat Transfer Class V Elementary School 2 Alue Teh This study aims to: 1) produce a product in the form of science teaching materials based on guided inquiry on heat transfer material; 2) describe the results of product validation based on guided inquiry teaching materials on the material heat transfer class $V$ Elementary School 2 Alue Teh; and 3) analyzing effectiveness science teaching materials based on guided inquiry on heat transfer material can improve student learning outcomes class V Elementary School 2 Alue Teh. Research This was carried out in class V of Alue Teh 2 Public Elementary School. This research is a Research Research \& amp; Development $(R \& D)$ includes Define (definition), Design (Design), Develop (development), and Disseminate (deployment). The design of teaching materials uses small group trials and large group trials which was conducted in class V Elementary School 2 Alue 2 Alue Teh. Data has been verified by 2 a material expert lecturer, and 2 design expert lecturers. Overall the results of expert validation the material obtained an average of $92 \%$ with the very feasible category while the results the design expert validation as a whole obtained an average of $95 \%$ in the category very worthy. At the effectiveness stage, the results showed that the second posttest data on the ability of student learning outcomes has a value of $t$ count $(=0,000)$ so there is a difference because sig (2-tailed) \& lt; 0.05 and t count is positive so that $\mathrm{H} O$ is rejected. Based on this, it can concluded that "there is a significant difference in learning outcomes among students who are taught using based teaching materials guided inquiry with students who are not taught to use inquiry guided.
Keywords guided inquiry; teaching materials; student learning outcomes

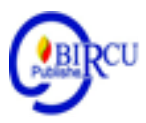

\section{Introduction}

The 21st century learning system is a learning transition with a developed curriculum that requires schools to change the teacher-centered learning approach to student-centered learning approaches. Students must have 4 skills, namely communication skills, collaboration, critical thinking and problem solving, creativity and innovation (communication, collaboration, critical thinking and problem solving, Creativity and Innovation) (Bahri, 2009). This competence is needed so that students have the ability to obtain, manage, and use information to survive in a situation that is always changing, uncertain, and competitive (Depdiknas, 2006). The implementation of science learning ideally trains and develops aspects of knowledge, critical thinking and scientific attitudes. This is in accordance with what is explained in the Annex to regulation of the minister of 
education Number 58 of 2014, that science learning should be carried out by inquiry (scientific inquiry) to foster the ability to think, work, and be scientific and communicate it, science learning also emphasizes providing direct learning experiences through the use of and the development of process skills and scientific attitudes (Kemendikbud, 2014).

Furthermore, Batemen and Strasser in Nasution (2020) stated that the reasons for studying organizational commitment are related to (a) employee behavior and performance effectiveness, (b) job satisfaction, (c) job and role characteristics, such as responsibilities and (d) personal characteristics of employees such as age, years of service. Natural Science is a science that can be learned to develop skills in the process of investigating the natural surroundings, solving problems and making decisions. In its objective, science is expected to be able to teach process skills so that students can investigate, solve problems, and be able to make decisions to solve these problems. Science learning in primary school / madrasah should provide real experiences to students by involving in their learning activities, it also needs to prevent students from verbalism. Science is concerned with finding out about nature systematically, so that science is expected to be a vehicle for students to learn on their own, discover, and develop the knowledge gained so that it is applied in everyday life. This understanding is often called constructivism pioneered by Jean Piaget. Based on the results of observations in class V Elementary School 2 Alue Teh, there are already available teaching materials that are owned by students, namely the theme book from the government. However, $100 \%$ of students stated that their teaching materials were not based on guided inquiry. The results of the questionnaire analysis on the needs of students in grade 2 Alue Teh show that the average percentage score who answered "yes" in agreeing to develop guided inquiry-based science teaching materials was $72.25 \%$, so it is necessary to develop science teaching materials based on guided inquiry.

So it takes appropriate inquiry learning for elementary school children, namely guided inquiry. Guided inquiry-based learning provides direct experience to students. Through direct experience, students can find facts, so they can learn to find knowledge, train KPS, and scientific attitudes. This is consistent with what Buxton \& Provenzo (2011) explained that "simple handson experiments become critical means by which learners can enter into the process of discovering science". It can be said that simple experiments are an important means for students to enter the process of discovering knowledge. Guided inquiry is the implementation of inquiry carried out on the instructions of the teacher. Starting from the core questions, the teacher asks various tracking questions with the aim of directing students to the expected conclusions. Furthermore, students conduct experiments to prove the opinions they express (Hanafiah et al, 2010). Several studies support that guided inquiry learning is able to improve students' science process skills (research Azizmalayeri et al. (2012), Lee et al. (2010) Prasojo (2016), Rani (2016)). The guided inquiry approach works best if there are teaching materials that support it.

Based on the above problems, the researcher conveyed the idea of developing teaching materials for science subjects. Educators have also never developed inquiry-based teaching materials. The development of teaching materials uses a guided inquiry-based learning model in science subjects. With the application of inquiry-based teaching materials in science learning at Alue Teh 2 Elementary Schools. The product produced from this research is expected to become one of the student book supplements based on the 2013 curriculum which is really needed by students at Alue Teh. This idea is manifested in the form of research with the title "Development of Guided Inquiry-Based Teaching Materials for Class V heat transfer material in elementary school 2 Alue Teh". 


\section{Research Methods}

The method used in this research is research and development ( R \& D), this research method aims to produce a product in the form of teaching materials or is included in development research. The R\&D model that will be used in this research is (1974). This model consists of 4 development stages, namely Define, Design (planning), Develop (development), and Disseminate (deployment). At the Define stage, it is carried out with initial analysis, student analysis, task analysis, concept analysis, and formulation of learning objectives. At the design stage, instrument preparation, media selection, format selection, and initial product design are carried out. At the Develop stage (development) includes the stage of expert assessment and field trials. In the Disseminate stage, it is only done in a limited manner, namely in class $\mathrm{V}$.

\section{Discussion}

\subsection{Initial Product Description}

This development research aims to develop instructional materials based on guided inquiry. This development uses a 4-D development model. The stages carried out are: the define stage, the design stage, the develop stage and the dissemination stage. The results of the development of each phase / stage in the development of this teaching material are as follows. Based on the results of observations in class V Elementary School 2 Alue Teh, there are already available teaching materials that are owned by students, namely theme books from the government. However, $100 \%$ of students stated that their teaching materials were not based on guided inquiry. The results of the questionnaire analysis of the needs of students in grade V elementary school 2 Alue The show that the average percentage score that answered "yes" in agreeing to do the development of guided inquirybased science teaching materials is $72.25 \%$, so it is necessary to develop guided inquirybased science teaching materials In addition, the results of the questionnaire in the preliminary research conducted at the Alue Teh public elementary school showed that 35 out of 40 students $(87.5 \%)$, who were given a questionnaire, stated that they had difficulty understanding the competencies that existed in heat material and its transfer. and 38 out of 40 people $(95.0 \%)$ stated that the learning resources and media used so far were inadequate.

The results of interviews with fifth grade teacher educators at public elementary school in 2 Alue Teh, it is known that in teaching educators using teaching materials that have been provided from the school, which is sourced from the government, namely printed books. Educators do not develop teaching materials according to student needs, what is provided by the government is what is taught to students. So that in the application of learning, the role of educators is more dominant than students in learning activities. Based on the above problems, it is necessary to develop inquiry-based teaching materials. The development of teaching materials uses a guided inquiry-based learning model in science subjects With the application of inquiry-based teaching materials in science learning at Alue Teh Elementary School 2. The product produced from this research is expected to become one of the student book supplements based on the 2013 curriculum which is really needed by students at Alue The 2 Elementary School. 


\subsection{Student Analysis}

Student analysis in this case was carried out on grade V elementary school students. Students in grade V elementary school, with an average age of 10-11 years, enter the final stage of concrete operations. The ability to think logically and systematically is able to solve problems, be able to develop strategies and be able to connect. His communication skills have developed along with the development of his thinking skills so that he is able to express thoughts in the form of logical and systematic word expressions. The development of socialization skills of fifth grade students who have been influenced by their peers so that groups are formed based on certain similarities.

\subsection{Task Analysis}

Task analysis aims to determine the content of the material and the competencies that must be achieved during the learning process. The preparation of teaching materials must refer to the Core Competencies (KI) and Basic Competencies (KD) in the 2013 Curriculum which are presented in a competency map. In this case the basic competencies developed in this study are 3.6 Applying the concept of heat transfer in everyday life.

\subsection{Concept Analysis}

Concept analysis is carried out to identify important concepts in learning that must be mastered by students. These concepts are arranged systematically and outlined in a concept map with the aim of making it easier for students to know what concepts to know.

\subsection{Formulation of Learning}

Objectives the development of teaching materials using guided inquiry is tailored to the learning objectives to be achieved. The purpose of developing this teaching material is to create concept maps, students are able to confidently explain how to transfer heat. By conducting experiments, students were able to investigate the correct conduction heat transfer.

\subsection{Cover Design}
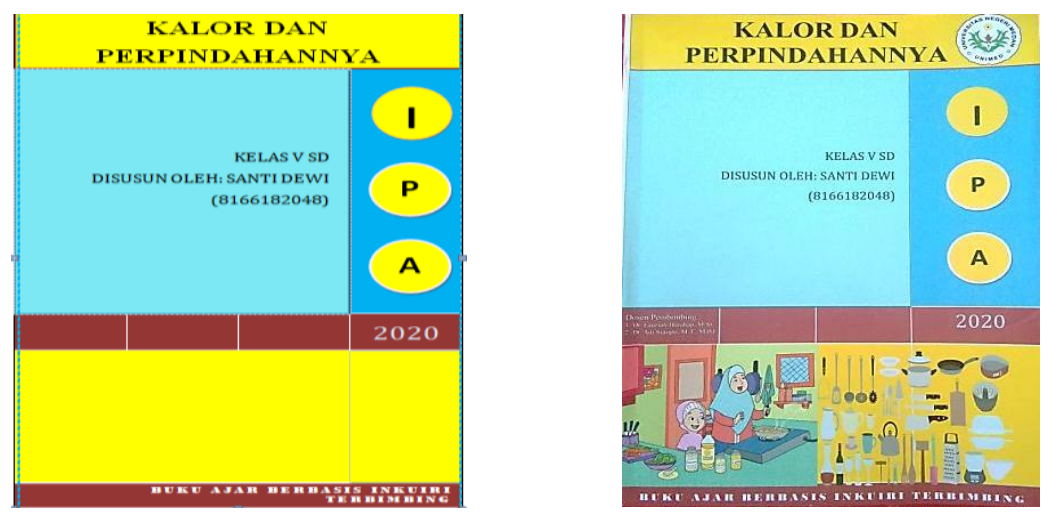

Figure 1. The Example of Cover Design

\subsection{Development Stage}

(Development) This teaching material was developed by taking into account the suggestions of the validator. The validators who play a role in the development of this teaching material are expert validators and design experts. It can be seen that the results of the material expert's validation at the first meeting can be seen that in the aspect of content 
feasibility, an average percentage of $96 \%$ is obtained in the very feasible category. In the first indicator, namely conformity with $\mathrm{KI}, \mathrm{KD}$, and Learning Objectives, an average of $100 \%$ is obtained in the very feasible category. In the second indicator, namely the truth of the substance of the learning material, an average of $100 \%$ is obtained in the very feasible category. In the ketia indicator, namely increasing students' knowledge based on their initial knowledge, obtaining an average score of $100 \%$ in the very feasible category. In the fourth indicator, namely inviting students to be active in learning to obtain an average score of $100 \%$ in the very feasible category. In the fifth indicator, the problems presented in accordance with everyday life get an average value of $100 \%$ in the very feasible category.

In the sixth indicator, namely providing learning experience and knowledge to students, an average of $75 \%$ is obtained in the feasible category. In the second aspect, namely the feasibility of language obtains an average percentage of $88 \%$ in the very feasible category. In the first indicator, the ease of understanding the language obtained an average of $88 \%$ with the very feasible category. In the second indicator, the language in the book is adjusted to the stage of development of students, getting an average of $100 \%$ in the very feasible category. In the third indicator, namely the clarity of information, an average of $75 \%$ is obtained in the feasible category. In the fourth indicator, namely the use of language effectively and efficiently, it gets an average of $88 \%$ in the very feasible category. In the presentation aspect, obtaining an average percentage of $90 \%$ in the very feasible category. In the first indicator, namely the clarity of the objectives to be achieved, an average of $88 \%$ is obtained with the very feasible category. In the second indicator, namely the table of contents and instructions for using easy-to-learn books, an average of $88 \%$ is obtained in the very feasible category.

In the fourth indicator, the image presented is related to and supports the clarity of the material, obtaining an average of $100 \%$ in the very feasible category. In the fifth indicator, namely the completeness of information, an average of $88 \%$ is obtained in the very feasible category. In the aspect of assessment, it gets an average of $88 \%$ in the very feasible category. In the first indicator, that is, the activities of students that are carried out to encourage students to explore, identify problems, submit hypotheses, collect and analyze data and reflect, get an average of $88 \%$ in the very feasible category. In the second indicator, which measures the achievement of the learning success indicators, an average of $75 \%$ is categorized as feasible. In the graphic aspect, it gets an average percentage of $85 \%$ in the very feasible category. In the first indicator, namely the use of type and size of letters, an average of $88 \%$ is obtained in the very feasible category. In the second indicator, the layout or layout obtains an average of $88 \%$ with the very feasible category. In the third indicator, the illustration or image gets an average of $88 \%$ with the very feasible category. In the fourth indicator, the book cover illustration describes the content / material presented with an average of $88 \%$ in the very feasible category.

In the fifth indicator, the display design gets an average of $88 \%$ in the very feasible category. In the sixth indicator, the physical appearance of the book can encourage reading interest and students' curiosity gets an average of $75 \%$ in the feasible category.

It can be seen that the results of the material expert's validation at the second meeting can be seen that in the aspect of content feasibility, an average percentage of $100 \%$ is obtained in the very feasible category. In the first indicator, namely conformity with KI, $\mathrm{KD}$, and Learning Objectives, an average of $100 \%$ is obtained in the very feasible category. In the second indicator, namely the truth of the substance of the learning material, an average of $100 \%$ is obtained in the very feasible category. In the ketia indicator, namely increasing students' knowledge based on their initial knowledge, 
obtaining an average score of $100 \%$ in the very feasible category. In the fourth indicator, namely inviting students to be active in learning to obtain an average score of $100 \%$ in the very feasible category. In the fifth indicator, the problems presented in accordance with everyday life get an average value of $100 \%$ in the very feasible category. In the sixth indicator, which is providing learning experience and knowledge to students, obtaining an average of $100 \%$ in the very feasible category. In the second aspect, namely the feasibility of language obtains an average percentage of $100 \%$ in the very feasible category. In the first indicator, the ease of understanding the language obtained an average of $100 \%$ with a very decent category. In the second indicator, the language in the book is adjusted to the stage of development of students, getting an average of $75 \%$ in the feasible category. In the third indicator, namely the clarity of information, an average of $75 \%$ is obtained in the feasible category.

In the fourth indicator, namely the use of language effectively and efficiently, it gets an average of $100 \%$ in the very feasible category. In the presentation aspect, obtaining an average percentage of $93 \%$ in the very feasible category. In the first indicator, namely the clarity of the objectives to be achieved, an average of $88 \%$ is obtained with the very feasible category. In the second indicator, namely the table of contents and instructions for using easy-to-learn books, it gets an average of $100 \%$ in the very feasible category. In the third indicator, namely the provision of motivation and attractiveness, an average of $88 \%$ is obtained in the very feasible category. In the fourth indicator, the image presented is related to and supports the clarity of the material, obtaining an average of $100 \%$ in the very feasible category. In the fifth indicator, namely the completeness of information, an average of $88 \%$ is obtained in the very feasible category. In the aspect of assessment, it gets an average of $94 \%$ in the very feasible category. In the first indicator, that is, the activities of students that are carried out to encourage students to explore, identify problems, submit hypotheses, collect and analyze data and reflect, get an average of $100 \%$ in the very feasible category.

In the second indicator, which is measuring the achievement of the learning success indicators, an average of $88 \%$ is obtained with the very feasible category. In the graphic aspect, it gets an average percentage of $94 \%$ in the very feasible category. In the first indicator, namely the use of type and size of letters, an average of $88 \%$ is obtained in the very feasible category. In the second indicator, the layout or layout obtains an average of $100 \%$ with the very feasible category. In the third indicator, the illustration or image gets an average of $100 \%$ with the very feasible category. In the fourth indicator, the book cover illustration describes the content / material delivered with an average of $100 \%$ in the very feasible category. In the fifth indicator, the display design gets an average of $88 \%$ in the very feasible category. In the sixth indicator, the physical appearance of the book can encourage reading interest and students' curiosity gets an average of $88 \%$ in the very feasible category.

\subsection{Development of Guided Inquiry-Based Teaching Materials on Heat Transfer Material}

The development of guided ikuiri-based teaching materials was developed using the 4-D model of research and development ( $R$ \& $D$ ) research design from Thiagarajan. The stages in this research are the define stage, the design stage, the develop stage, and the dissemination stage. In the initial analysis of this research, it aims to raise and determine the problems faced in learning activities. The problems faced by students are 1) Lack of supplementary teaching materials for the 2013 curriculum with Guided Inquiry-based learning; 2) Lack of teacher creativity in developing teaching materials that have 
attractiveness, convenience and benefits; and 3) Lack of effectiveness of science learning, so that student learning outcomes do not reach the KKM score. In addition, based on observations made in class V $100 \%$ of students stated that the teaching materials they had were not based on guided inquiry. Therefore, guided inquiry-based teaching materials for fifth grade elementary schools were developed. This teaching material has been developed based on the characteristics of grade $\mathrm{V}$ elementary school students, whose average age is 10-11 years, enter the final stage of concrete operations. The ability to think logically and systematically, be able to solve problems, be able to develop strategies and be able to connect. Furthermore, this teaching material is prepared based on Core Competencies (KI) and Basic Competencies (KD) in the 2013 Curriculum which are presented in a competency map.

The concept developed in this teaching material is based on class $\mathrm{V}$ material, namely heat and its displacement. These concepts are arranged systematically and outlined in a concept map with the aim of making it easier for students to know what concepts to know. The purpose of developing this teaching material is to create concept maps, students are able to confidently explain how to transfer heat. By conducting experiments, students were able to investigate the correct conduction heat transfer. At the design stage, there are three steps: first, compiling a benchmark reference test. Second, the selection of learning media. Third, choosing the format for writing teaching materials. Fourth, the initial design of the product design. Furthermore, the teaching materials that have been designed are validated by material experts and inquiry-based teaching material design experts. This data is in accordance with research conducted by Erna Novitasari in the Inquiry Journal of the Science Education Megister Program, Faculty of Teacher Training and Education, Sebelas Maret University (volume 5, no.1, 2016, page 112-121) with the title Development of Science Teaching Teaching Materials Integrated Based On Guided Inquiry Theme of Sun and Alternative Energy Sources in Class VII.

The results of this study are: (1) produce an Integrated Science module with the theme of the Sun as an alternative energy source, developed with a guided inquiry-based learning component and using a 4-D development model including Define, Design, Develop, and Disseminate, (2) Integrated Science Module based on guided inquiry with the theme of the sun as an alternative energy source that has been tested by expert lecturers, science teachers (reviewers) and peers (peer review). Based on the test results, it shows that the Integrated Science module based on guided inquiry with the theme of the sun as an alternative energy source is suitable for use in learning learning activities, (3) the Integrated Science module with the theme of the Sun as an effective alternative energy source to improve student learning outcomes, the average pretest and posttest scores students who use the Integrated Science module are larger than students who do not use the Integrated Science module. This inquiry-based teaching material can foster the ability to think, work, move forward according to its abilities and be scientific in every action, and communicate it to others. Science lessons also emphasize providing direct experience through developing process skills, scientific attitudes in each practice. Inquiry activities allow students to find certain concepts through a series of scientific activities that can make students strengthen their personality by directing their own learning through teacher guidance.

\subsection{Product Validation Results of Guided Inquiry-Based Teaching Materials on Heat Transfer}

Material Based on the teaching materials that have been designed and developed, it is then validated first by material experts and design experts. The results of the material 
expert's validation at the first meeting can be seen that in the aspect of content feasibility, namely the first indicator regarding the feasibility of the content obtains an average percentage of $96 \%$ in the very feasible category. In the second aspect, namely the feasibility of language obtains an average percentage of $88 \%$ in the very feasible category. In the presentation aspect, obtaining an average percentage of $90 \%$ in the very feasible category. In the aspect of assessment, it gets an average of $88 \%$ in the very feasible category. In the graphic aspect, it gets an average percentage of $85 \%$ in the very feasible category. After revising the validation results of material experts at the first meeting, it can be seen that in the aspect of content feasibility, namely the first indicator regarding content feasibility, the average percentage is $100 \%$ in the very feasible category. In the second aspect, namely the feasibility of language obtains an average percentage of $88 \%$ in the very feasible category.

In the presentation aspect, obtaining an average percentage of $94 \%$ in the very feasible category. In the assessment aspect, it gets an average of $93 \%$ in the very feasible category. In the graphic aspect, it gets an average percentage of $94 \%$ in the very feasible category. Furthermore, the teaching materials are validated by design experts. The results of the design expert validation on the display aspect obtained an average of $66 \%$ in the feasible category. In the content aspect, it gets an average of $77 \%$ in the feasible category. In the writing aspect, it gets an average score of $96 \%$ with the very feasible category. After the revision was carried out, the results of the design expert's validation after revision on the display aspect obtained an average of $91 \%$ in the very feasible category. In the content aspect, it gets an average of $94 \%$ in the very feasible category. In the writing aspect, it gets an average score of $100 \%$ with the very feasible category. Valid teaching materials are then tested on individuals, small groups and large groups. The results of individual trials can be seen that students' responses to inquiry-based teaching materials seen from the attractiveness of the display obtained an average of $69 \%$ in the sufficient category. Student responses to inquiry-based teaching materials seen from the ease have an average of $75 \%$ in the good category. Student responses to inquiry-based teaching materials seen from openness have an average of $59 \%$ in the sufficient category.

Overall, the average student response to teaching materials reached $67 \%$ in the sufficient category. The results of small group trials on inquiry-based teaching materials seen from the attractiveness of the display obtained an average of $80 \%$ in the good category. Student responses to inquiry-based teaching materials seen from the ease have an average of $78 \%$ in the good category. Student responses to inquiry-based teaching materials seen from openness have an average of $69 \%$ in the good category. The average student response to teaching materials in the large group reached $76 \%$ with a good category. The results of large group trials of student responses to inquiry-based teaching materials seen from the attractiveness of the display obtained an average of $71 \%$ in the good category. Student responses to inquiry-based teaching materials seen from the ease have an average of $71 \%$ in the good category. Student responses to inquiry-based teaching materials seen from openness have an average of $74 \%$ in the good category. The average student response to teaching materials in the large group reached $90 \%$ with the very good category.

In addition to student responses, there was a teacher response to teaching materials which was carried out in two stages, namely the first validation and the second validation. The results of the teacher's response to inquiry-based teaching materials in the first validation obtained an average value of $75 \%$ in the good category. The results of the teacher's response to the second validation obtained an average of $93 \%$ in the very good category. The results of the study are in line with research conducted by Noerlidah alias, 
Faculty of Education, University of Malaya, Kuala Lumpur, Malaysia. The Turkish Online Journal of Educational Technology in 2012, volume 11 no 4 pages 84-93, entitled Design and Development of physics Ajare materials Based on Learning style and Appropriate Technology By Employing Isman instructional Design Model. This study aims to design and develop a physics module based on learning styles and to test the module's effectiveness. This paper draws attention to design principles. The prototype module was tested between two teachers and 14 participants. Findings from interviews with teachers and students showed a positive response in physics when their learning styles were matched with appropriate technology. At the evaluation stage, two instruments were used to collect data for this study.

\section{Conclusion}

Based on the results of research that has been carried out, analyzed and discussed, the following conclusions are obtained in this study: 1. This guided inquiry based teaching material is developed based on 4-D stages. The stages carried out are: the define stage, the design stage, the develop stage and the dissemination stage. This teaching material is carried out by an initial analysis of the needs of students, teachers and schools. Teaching materials were developed based on the characteristics of grade $\mathrm{V}$ elementary school students. This teaching material is also developed based on the 2013 curriculum competency and is integrated with the guided inquiry stage. 2. The validation of this teaching material product has been validated by 4 experts, namely 2 material experts and 2 design experts who are postgraduate lecturers at the State University of Medan. Overall the results of the material expert validation obtained an average of $92 \%$ in the very feasible category while the results of the design expert validation as a whole obtained an average of $95 \%$ in the very feasible category. 3. The results showed that the two post-test data on the ability of student learning outcomes had a t-count value $(=0,000)$ so there was a difference because sig (2-tailed) $<0.05$ and tcount was positive so that $\mathrm{H} 0$ was rejected. Based on this, it can be concluded that "there is a significant difference in learning outcomes between students who are taught using guided inquiry-based teaching materials and students who are not taught using guided inquiry.

\section{References}

Abdurrahman. 2015. Science Teachers as Innovators: Designing research-based innovative science learning. Yogyakarta: Media Academy.

Afrida, J. Adlim, Halim, A. 2015. Development of Guided Inquiry-Based Student Worksheets to Improve Science Process Skills and Student Interest in Learning Static Fluid AT SMA Negeri 11 Banda Aceh. Indonesian Journal of Science Education, Vol. 3 (1): 93-106 Azizmalayeri, K., Mirshahjafari, E., Sharif, M., Asgari, M., \& Omidi, M. 2012. The impact of guided inquiry methods of teaching on the critical thinking of high school students. Journal of education and practice. 3 (10).

Buxton, E.A., \& Provenzo, E.F. Jr. (2011). Teaching science in elementary and middle school: a cognitive and cultural approach (2nded). California: SAGE Publications, Inc.

Chrisyanto, P, 2013. The Effect of Using Student Worksheets (LKS) Based on Students' Science Process Skills on the Main Material of Diversity in Life Organizational 
Systems. (Quasi Experimental Class VII Semester Even Semester SMP Negeri 22 Bandar Lampung Academic Year 2012/2013. (Abstract). Bandar Lampung: UNILA Damayanti, D.S., Ngazizah, N., And Setyadi, K.E. 2013. Development of Student Worksheets (LKS) with Guided Inquiry Approach to Optimize Students' Critical Thinking Ability in Dynamic Electrical Material at SMA Negeri 3 Purworejo Class $X$ in Academic Year 2012/2013. Radiation, 3 (1): 58-62.

Depdiknas, 2006. Permendiknas No. 22 of 2006 on Content Standards for Primary and Secondary Education Units in Appendix 3 Competency Standards and Basic Competencies for SD, MI, SDLB, SMP, MTS, and SMPLB. Eko Jaya. Jakarta.

Dimyati, .Mudjono.2009. Learning and Learning. Jakarta: Rineka Cipta Firdaus, M and Wilujeng, I. 2018. Development of guided inquiry LKPD to improve critical thinking skills and learning outcomes of students. Journal of Science Education Innovation, 4 (1). 26-40.

Fraenkel, J.R., Wallen, N.E., And Hyun, H.H. 2012. How to Design and Evaluated Reasearh in Education, New York: The McGraw-Hill Companies Hanafiah, Nanang \& Suhana, Grandchildren. 2010. Concept Learning Strategy. Bandung: Refika Aditama.

Hanafiah, Nanang \& Suhana, Grandchildren. 2010. Concept Learning Strategy. Bandung: Refika Aditama.

Haryanto.2004. Science Volume 5. Jakarta: Erlangg.

Hosnan M. 2013. Scientific and contextual approaches in 21st Century Learning. Jakarta: Ghalia Indonesia Jufri, wahab. 2018. Learning and Learning Science. Bandung: Pustaka Reka Cipta.

Kartono, Teguh Purwantari ,. 2010. Natural Sciences 4. Jakarta: Pusat Books, Ministry of National Education.

Lee, W.J., Puspitasari, K.A., Kim., H.Y., \& Jeong, A. 2010. The Effects of Guide Inquiry Questions on Students Critical Thinking Skills and Satisfaction in Online Argumentation. Journal of Florid. 1 (1), 156-162.

Martin, R., Sexton C., Franklin T. \& Gerlovich J. (2005). Teaching science for all children: inquiry method for contructing understanding (3thed). Boston, MA: Pearson Education, Inc.

Ministry of Education and Culture. (2014). Regulation of the Minister of Education and Culture Number 582014 concerning the 2013 Junior High School / Madrasah Tsanawiyah Curriculum.

Nasution, K.P., Zainuddin, and Rahman, A. (2020). The Influence of Individual Caring and Organizational Trust on Organizational Commitment of Private LPTK Lecturers in Medan City. Budapest International Research and Critics in Linguistics and Education (BirLE) Journal Vol 3 (3): 1537-1550.

OECD. 2015. PISA 2009 Assessment Framework - Key Competencies In Reading, Mathematics And Science. Paris: Organization for Economic Cooperation and Development (OECD).

Prasojo. 2016. Development of Guided Inquiry-Based Science Learning Tools to Improve KPS and Critical Thinking. Journal of Mathematics and Science Education, 4 (2), 2016, 130-141.

Prastowo. Andi. 2015. Creative Guide to Making Innovative Teaching Materials. Diva Press. Yogjakarta.

Purwanto, N., and Surjaman, T. 2004. Teaching Evaluation Principles and Techniques. Bandung: Youth Rosdakarya. 
Puspita, A.R, Paidi, and Nurcahyo, H. 2017. Analysis of Science Process Skills Cell LKPD in Bekasi City Public High School. Journal of Biology Education Study Program, 6 (3): 164-170.

Rani, Islamiar N, Paidi, Wilujeng, I. 2016. The development of worksheets for science students with the guided inquiry approach to the material "solar system" to improve students' process skills. Journal of Mathematics and Science Education, 5 (1), 1-8.

Rahmi, R, Hartini, S., and Wati, M. 2014. Development of Guided Inquiry Based Student Worksheets (LKS) and Multimedia Learning Science in Junior High Schools. Periodic Scientific Physical Education, 2 (2): 240-256.

Riduwan. 2012. Easy Learning Research for Employee Teachers and Beginner Researchers. Bndung: Alfabeta.

Rohaeti, E, Widjajanti, E and Padmaningrum, RT. 2009. Development of Student Worksheets (LKS) for Chemical Science Subjects for Junior High Schools. Journal of Educational Innovation 10 (1). 1 - 11.

Sudijono, A. 2010. Introduction to Educational Statistics. Jakarta: Raja Grapindo Persada.

Suansah. 2015. Application of the Inquiry Approach to Improve Student's Process Skills in Natural Science Learning on the Subject of Heat Conductors and Insulators, Basic Education Profession, 2 (1) .59-67 S.

Usanti, Supardi, and Indana, (2016), Development of Natural Science Learning Tools Guided Inquiry Model for Practicing Science Process Skills Junior High School Student, Journal of Science Education, 6(1): 1256. 